\title{
The Learning to Learn Competence in Early Childhood Preservice Teachers: An Outdoor and e/m-Learning Experience in the Museum
}

\author{
Daniel Abril-López ${ }^{1, *(\mathbb{D}}$, Hortensia Morón-Monge ${ }^{2}$, María del Carmen Morón-Monge ${ }^{3}$ \\ and María Dolores López Carrillo ${ }^{1}$ (D) \\ 1 Departamento de Geología, Geografía y Medio Ambiente, Universidad de Alcalá, 19001 Guadalajara, Spain; \\ mariadolores.lopez@uah.es \\ 2 Departamento de Didáctica de Ciencias Experimentales y Sociales, Universidad de Sevilla, 41013 Sevilla, \\ Spain; hmoron@us.es \\ 3 Departamento de Didácticas Integradas, Universidad de Huelva, 21007 Huelva, Spain; \\ mcarmen.moron@dhis2.uhu.es \\ * Correspondence: daniel.abril@uah.es
}

Citation: Abril-López, D.; Morón-Monge, H.; Morón-Monge, M.d.C.; López Carrillo, M.D. The Learning to Learn Competence in Early Childhood Preservice Teachers: An Outdoor and e/m-Learning Experience in the Museum. Future Internet 2021, 13, 25.

https://doi.org/10.3390/fi13020025

Academic Editor: Antonio José Moreno Guerrero

Received: 31 December 2020

Accepted: 21 January 2021

Published: 23 January 2021

Publisher's Note: MDPI stays neutral with regard to jurisdictional claims in published maps and institutional affiliations.

Copyright: (c) 2021 by the authors. Licensee MDPI, Basel, Switzerland. This article is an open access article distributed under the terms and conditions of the Creative Commons Attribution (CC BY) license (https:/ / creativecommons.org/licenses/by/ $4.0 /)$.

\begin{abstract}
This study was developed with Early Childhood Preservice Teachers within the framework of the Teaching and Learning of Social Sciences over three academic years (2017-2018, 2018-2019, and 2019-2020) at the University of Alcalá. The main objective was to improve the learning to learn competence during teacher training from an outdoor experience at the Museum of Guadalajara (Spain), using e/m-learning tools (Blackboard Learn, Google Forms, QR codes, and websites) and the inquiry-based learning approach. To ascertain the level of acquisition of this competence in those teachers who were being trained, their self-perception-before and after-of the outdoor experience was assessed through a system of categories adapted from the European Commission. The results show a certain improvement in this competence in Early Childhood Preservice Teachers. Additionally, this outdoor experience shows the insufficient educational adaptation of the museum to the early childhood education stage from a social sciences point of view. Finally, we highlight the importance of carrying out outdoor experiences from an inquiry-based education approach. These outdoor experiences should be carried out in places like museums to encourage contextualized and experiential learning of the youngest in formal education.
\end{abstract}

Keywords: Early Childhood Preservice Teachers; social sciences; learning to learn competence; museum; outdoor learning; inquiry-based learning; e/m-learning

\section{Introduction}

The society of the 21st century is living in a special period, with great socio-environmental problems and inequalities. The complexity and the changing world, combined with its new socio-scientific issues, have created the need to enforce the education of our population [1,2]. The recent global health crisis caused by COVID-19 and the climate emergency are a few examples of the consequences of the environmental imbalance and socio-environmental problems in the world today [3,4]. For this reason, one of the current challenges of the educational system is to provide people with proper tools that will allow them to face this changing reality. In this sense, different national and international reports and evaluations call for competency-based teaching, such as the Programme for International Student Assessment (PISA) report [5]. One of the most widely demanded competencies today is the ability of learning to learn [6].

As teacher educators, we believe that it is necessary to design teaching experiences based on competences with our Early Childhood Preservice Teachers (hereinafter ECPT). In this sense, we focus on the learning to learn competence in this study. We think that it is a key competence for building societal knowledge [7] and indispensable for university 
students [8], especially for ECPT, due to the cascade effect that their profession has on society.

Similarly, it is necessary that we analyze which teaching experiences are the most appropriate for development of the learning to learn competence. The design of educational proposals must be accompanied by evaluation instruments that allow us to objectively and systematically assess the teaching scope of our proposals. In this study, our main evaluation instrument is the ECPT's self-perception of their level of competence acquisition.

Therefore, our research has two main aims: First, to present an outdoor experience as innovative and educational using e/m-learning tools from an inquiry-based learning approach, and second, after completing the educational experience, to assess the scope level of the proposal from the ECPT's self-perception of their learning to learn competence. To achieve this, we designed an outdoor experience in a museum, where our ECPT collected data and analyzed the results to solve a research question related to the teaching opportunities offered by the museum as an educational resource for children. Other similar studies that promote contextualized learning from outdoor experiences and e $/ \mathrm{m}$-learning tools are the proposals of Rogers et al. [9], Chen and Huang [10], and Pierroux et al. [11]. However, in Spain, there are not many educational experiences in teacher training like the one described herein.

However, what do we mean by competencies? In particular, why do we consider it relevant to develop learning to learn competence with ECPT? We address these issues in the following sections in order to justify our study.

\subsection{Competences in the Educative Curriculum for Childhood Education}

The concept of competence is a recent insertion in the educational curriculum. Its conceptual complexity and the different conceptualizations in the legislation of each country and European and international reports make this an imprecise and undefined concept [12-14]. The Organization for Economic Co-operation and Development (OECD) [15] (p. 8) provides the following definition: "Key competences involve a mobilization of cognitive and practical skills, creative abilities and other psychosocial resources such as attitudes, motivation and values".

Competencies are a combination of knowledge, capacities, and attitudes appropriate to the context that promote permanent teaching and learning processes in a world with constant changes and that is becoming increasingly interconnected [7]. The competences are relevant in terms of personal fulfillment, active citizenship, adult life, and work, which are aspects closely linked to the area of social sciences education.

Spanish regulations establish the objective of a basic, open, and flexible general curriculum. Curriculum is equivalent, in the Anglo-Saxon world, to the "official curriculum" [16], or "national curriculum document" [17]. There are seven educational competences included in the Spanish regulations for the educational curriculum in Order ECD/65/2015 [18], under the term "key competences", from primary to compulsory secondary education. However, there is no explicit mention of competencies for the early childhood education stage. Authors such as Muñoz et al. [19] state that, at this stage, the prerequisites are set for learning of the infant in the future.

On the other hand, there are also regional regulations that have their specific frameworks and schools develop individual curricula, accordingly. This is important because regional regulations are affected by factors such as different historical scenarios and sociocultural and natural contexts [20]. Our study is part of the regional area of Castilla-La Mancha (Spain), and in this region, its educational curriculum explicitly contemplates nine competencies for the early childhood education stage [21,22]: Linguistic communication; mathematics; knowledge of and interaction with the physical, information, and digital world; social and civic; cultural and artistic; learning to learn; autonomy and personal; and emotional initiative. In general, a set of competencies for early childhood education (children from 0 to 6 years old) should promote observation, manipulation, and active exploration for the collection of information and interpretation of reality. Other aspects that stand out are the promotion of simple "cause-effect" relationships, basic rules, the 
adequate use of time and space, and the use of materials and resources in an orderly and appropriate manner.

Despite these circumstances, studies on competencies in the early childhood education stage are not abundant. Several previous studies on the competencies in early childhood education are those by Muñoz [23] and Vieites [24] from an integrative point of view and under a socio-constructivist and holistic theory, and the study by Ureña [25] in a school in Paris (France).

\subsection{Learning to Learn for Lifelong Learning}

As we have justified above, learning to learn is one of the competences required to face this complex and changing world. Learning to learn is an essential strategy for the survival of human beings through their adaptation to the changing environment [26]. This competence guarantees that the individual is able to respond to a rapidly changing society, through continuous learning throughout their life, as stated in the "Memorandum on Lifelong Learning" [7].

Hautamäki et al. [27] (p. 39) define the learning to learn competence as "the ability and willingness to adapt to new tasks, by activating the commitment to think and a perspective of hope through the maintenance of cognitive and affective self-regulation in the learning activity". According to Recommendation 2006/962/EC [7] (p. 16), "Learning to learn is the ability to pursue and persist in learning, to organize one's own learning, including through effective management of time and information, both individually and in groups". This competence addresses three educational dimensions [28]: Affective (motivation, self-esteem, and learning environment); cognitive (rules and mental instruments); and metacognition (solving problems).

The ability of learning to learn requires the ability to use all of our senses (sight, hearing, smell, touch, and taste) and our interaction with the environment to build knowledge. This ability is maximized if we know how to use the potential of all the physical stimuli that we receive, together with our mathematical and linguistic intelligence, to learn [6]. As teacher trainers, a deep analysis of what we understand as learning is required to teach how to learn. This means, from a practical level, the exhaustive and detailed design of activities aimed to achieve this competence from any area of knowledge [29]. Therefore, it is necessary to attend to different educational aspects involved in the teaching-learning processes, such as previous ideas, protagonism and autonomy, planning and realism, knowledge, skills and strategies, reflection and supervision, and evaluation.

From this perspective, this competence is understood as the basis of learning [30]. To develop this ability, many authors defend the value of experiential learning for promoting the ability of learning to learn [31]. In the early childhood education stage, experiential learning takes on special importance, since the child explores and builds their world based on the direct interaction between their senses and the environment [32-34].

In this sense, outdoor education encourages this type of experiential learning [3,6,35]. For this reason, the teaching situation under which this research is carried out is an outdoor experience aimed at developing the learning to learn competence.

\subsection{Outdoor Education from an Inquiry-Based Learning and e/m-Learning Approach: Opportunities for Education in COVID-19 Times}

The growing interest in seeking new ways of teaching and learning for the acquisition of competences, and the sanitary crisis that we are currently experiencing, justify the special attention that is being paid to integrating field trips, in order to complement and enhance formal teaching. This explains the current trend of investigating training possibilities in other less conventional learning scenarios, such as those promoted by the Manifesto for Outdoor Education [31].

Field trips in the teaching of social sciences have been developed for a long time [36]. Their educational importance appears in the educational curricula of Spain, from the stage of early childhood education to university education [3,6,37-39]. Despite these circumstances, field trips in Spanish schools are usually carried out as non-scheduled activities, 
decontextualized from the educational program, and from a traditional perspective of science [3,40-42].

Our outdoor experience, consisting of a field trip to the Guadalajara Museum (Spain) with the ECPT, corresponds to an educational model based on the acquisition of competences, especially learning to learn, from an inquiry-based learning and e/m-learning approach [43-46]. This approach is characterized by focusing on the student, who establishes their own work plan, and formulates real, close, and observable problems that connect with their interest and that can be raised with the help of the teacher [41]. From this approach, field trips promote the development of scientific knowledge and skills for solving problems, using one's own e/m-learning tools.

In today's world, e/m-learning has a very important role, especially among the younger population born in the digital era of new information technologies. E-learning or electronic learning involves a multimedia system (text, audio, video, and imagery) for carrying out virtual training over the Internet [47], characterized by its simplicity of use and lack of distance between the transmitter and receiver, as well as the fact that it is economical for students, interactive, and accessible. M-learning or mobile learning is a branch of m-learning with the following purpose: "Promote information collection and exchange, improve communication and collaborative interaction, encourage active learning, and enhance the learner's feedback process, and acquire content quickly" [48] (p. 1124).

For this outdoor experience, inquiry-based learning and an e/m-learning approach were integrated. This proposal is interesting for developing skills such as learning to learn, and it can act as a benchmark in times of pandemic, where multimodal or blended teaching becomes especially relevant. Likewise, the combination of virtual teaching with outdoor activities entails a lower probability of contagion.

\subsection{Museums and Social Science Teaching}

Museums are defined as "classrooms without walls". They are known to be important educational environments and offer a considerable learning potential: Multifaceted experiential learning and as living environments during life-long learning [34].

From an educational point of view, the museums of the 21st century face the great challenge of attending to competency teaching by adapting their way of communicating to new technologies [49]. In particular, in the area of social sciences, museums must show a global perception of six major areas, including space, time, society, politics, economy, and culture [50-52]. The relations between museums, heritage, and education must maintain an interdisciplinary, holistic, constructivist, and socio-critical vision [53,54].

The educational proposals of schools have been complemented with outdoor activities such as visits to museums or settlements/sites and colonies, and prehistory workshops [55]. The learning scenarios can be numerous if the teacher knows how to use them. Each space (museums, parks, aquariums, botanical gardens, etc.) offers a multitude of educational opportunities where outdoor experiences can be developed [3].

Despite this, in Spain, there are still few outdoor educational proposals for the early childhood education stage, and even less from the educational perspective that we promote here. The aim is to promote the potential of heritage education as an educational resource. Some outdoor experiences in early childhood, in the Spanish context, are that of Pérez Melgar and Morón [56] using a historical park (María Luisa Park) in the city of Seville as a learning setting, and the outdoor experience of León [57] in an aquarium. In these cases, the design was based on the performance of motivation/introduction, development, and reflection/synthesis activities using several clues. The results reflected the increase in the direct interaction of students with the environment, the interaction between identity and heritage, and the promotion of heritage conservation and biodiversity.

Other educational experiences during the early childhood stage are developed in museums to work on specific knowledge, such as that described by Bardavio, Mañé, Pizarro and Vila [58] in the form of workshops and activities on the understanding and 
preservation of archaeological heritage with early childhood education students. The results contributed to the modification of previous ideas (stereotypes), historical knowledge, active participation, and the rights and duties of citizens, through a didactic strategy of guided discovery.

De los Reyes [59], through a proposal called the "children's classroom museum", aimed at children from 5 to 8 years old, focused on children learning about the past from their relationships with the present. The daily objects used were turned into historical objects. Therefore, an inductive research method was employed for observation, description, documentation, classification, and interpretation, which facilitated the valuation of cultural heritage (family and social).

Escribano-Miralles and Molina [60] conducted a tour of the Ramón Gaya Museum (Murcia, Spain) from an inquiring perspective, with 5-year-old children. The qualitative and quantitative results confirmed the high degree of satisfaction and motivation of the students, and their greater relationship with the artistic heritage. This was thanks to the development of four phases (questions, new information, structuring, and learning).

Domínguez Castro and Pineda Alfonso [61] developed an experience based on art and creativity, in fine arts centers of Seville (Spain), through activities and drawings for 5-year-olds, in order to overcome the traditional educational cards. The results of the various activities contributed to an improvement in the originality and creativity of the students, through the use of a category system and a progression hypothesis.

At the international level, and from a non-formal education perspective, museums are increasing their services for very young children, offering a greater number of educational proposals adapted to infants [62,63]. However, there are still few outdoor experiences dedicated to early childhood education [64], and fewer educational proposals developed for formal education in museums.

Considering this scenario, we selected the Guadalajara Museum due to it exhibiting contents that cover practically all areas of social sciences, showing past and current material. This museum can also work on other educational areas from a global approach, as recommended for the early childhood education stage.

\section{Materials and Methods}

\subsection{Methodology}

The methodology of this research is qualitative, and is characterized by the description, analysis, and interpretation of complex phenomena from a social perspective [65]. From this perspective, we designed our main data collection and analysis instrument, shaped by different complex levels [66,67].

Figure 1 synthetically presents the study. The research question is as follows: How do the ECPT improve the learning to learn competence after their experience in the museum? To approach this question, we designed a category system-like data collection and analysis instrument based on the European Commission about the learning to learn competence [68].

With this instrument, the ECPT's self-perception was assessed at two moments of the teaching and learning process (pre-test and post-test). This outdoor experience is based on an inquiry and e/m-learning approach. To do this, the ECPT had to answer a mean research question on designing educational proposals adapted to early childhood. These educational proposals were evaluated with an evaluation rubric that complemented the results of self-perception. Although this study focuses on the self-perception of competence, assessing the process followed by the outdoor experience gives a holistic vision of the teaching-learning process developed. 


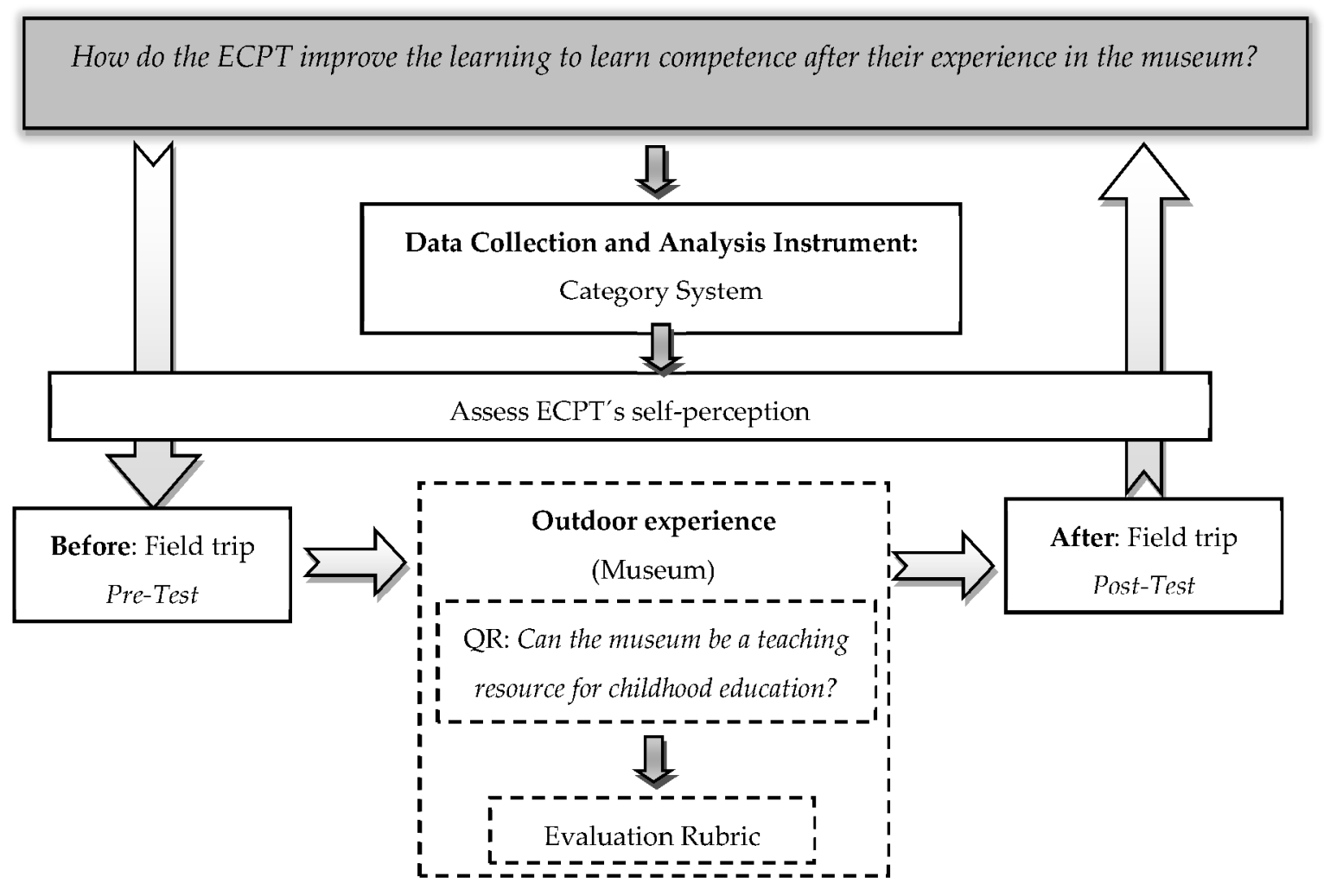

Figure 1. Outline of the investigation.

\subsection{Participants}

This educational experience was carried out with a group of 258 Early Childhood Preservice Teachers (University of Alcalá, Spain), as part of the subject Teaching and Learning of Social Sciences (Campus de Guadalajara), during three academic courses: 2017-2018 (68 students); 2018-2019 (66 students); and 2019-2020 (124 students). In the sample, there were 244 women (94.57\%) and 14 men (5.43\%).

\subsection{Category System: Assess ECPT's Self-Perception}

We present a category system with four levels of progression (Table 1), published by the European Commission (2012) [68], for the evaluation of the acquisition of learning to learn competence. Levels of learning progression are levels of complexity of knowledge from reductive to holistic thought $[1,69,70]$. The category system justifies and structures the whole research $[3,71]$.

This system was implemented in the Lithuanian educational system, which "demonstrates how the 'learning to learn' competence can be described as levels that help learners and their teachers to assess progress" [68] (p. 16).

The students accessed "Blackboard Learn" (Figure 2) to fill in the questionnaire by levels of progression, which were disordered to avoid distortions. This questionnaire was designed in Google Forms, which the students accessed from a QR code (Figure 3). The use of these open access digital tools, through mobile devices, provides students with a positive, innovative, and current image of education [72], and allows information to be collected in an efficient and effective manner [73]. 
Table 1. Category system for the learning to learn competence. Own elaboration based on the European Commission [68].

\begin{tabular}{|c|c|c|}
\hline Dimensions & Level & Descriptors \\
\hline \multirow{4}{*}{ 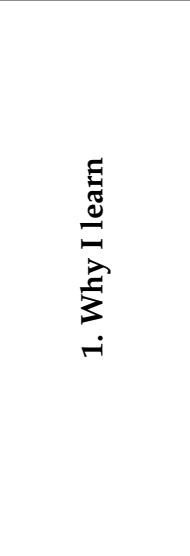 } & I & $\begin{array}{l}\text { I learn when others urge, encourage, and persuade me. I feel secure when somebody helps me. } \\
\text { When I work together with others, I observe more often how others are doing things. }\end{array}$ \\
\hline & II & $\begin{array}{l}\text { I learn because I have to, but I eagerly learn only what I am interested in. I am self-confident when } \\
\text { I have to complete easily understandable tasks. When I work together with others, I try to express } \\
\text { my opinion. }\end{array}$ \\
\hline & III & $\begin{array}{l}\text { I understand that learning is my duty and I therefore try to learn not only things that I am } \\
\text { interested in. I usually feel self-confident when I have to perform both usual and new noncomplex } \\
\text { tasks, and I am not afraid of making mistakes. When I work together with others, I often express } \\
\text { my opinion and I help others whenever I can. }\end{array}$ \\
\hline & IV & $\begin{array}{l}\text { I learn eagerly and responsibly, because I like learning and understand that what I learn now will } \\
\text { serve me in the future. I am self-confident, I am not afraid of challenges, and I welcome various } \\
\text { new tasks. When working together with others, I not only learn from them, but also help them } \\
\text { eagerly and confidently. }\end{array}$ \\
\hline \multirow{4}{*}{ 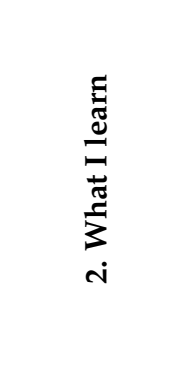 } & I & $\begin{array}{l}\text { I set learning goals and plan learning activities when others help me. I manage to complete tasks } \\
\text { on time when others urge me to. }\end{array}$ \\
\hline & II & $\begin{array}{l}\text { I consult others to set my learning goals and plan my learning activities. I manage to complete } \\
\text { certain tasks on time. }\end{array}$ \\
\hline & III & $\begin{array}{l}\text { I try to set my learning goals autonomously and plan my learning activities. I usually manage to } \\
\text { adhere to the schedule and complete tasks on time. }\end{array}$ \\
\hline & IV & $\begin{array}{l}\text { I set my learning goals autonomously. I successfully plan my learning and am therefore able to } \\
\text { complete most tasks and tests on time. }\end{array}$ \\
\hline \multirow{4}{*}{ 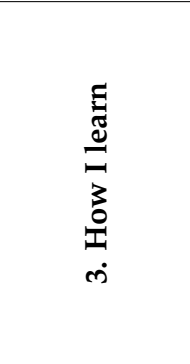 } & I & $\begin{array}{l}\text { I use learning methods and choose information sources and learning tools which are offered to me } \\
\text { by others. }\end{array}$ \\
\hline & II & $\begin{array}{l}\text { With the help of others, I decide what learning method, learning tools, and information sources are } \\
\text { best for performing a certain task. }\end{array}$ \\
\hline & III & $\begin{array}{l}\text { I try to use different learning methods and I use various information sources. I try to obtain any } \\
\text { required learning tools in advance. }\end{array}$ \\
\hline & IV & $\begin{array}{l}\text { I successfully use various learning methods and choose appropriate information sources. I obtain } \\
\text { any required learning tools in advance. }\end{array}$ \\
\hline \multirow{4}{*}{ 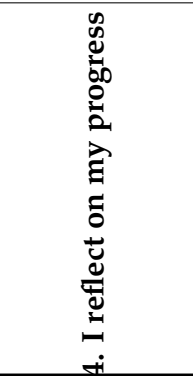 } & I & $\begin{array}{l}\text { When others help and encourage me, I observe my learning progress and sometimes listen to } \\
\text { advice given to me and try to follow the advice. }\end{array}$ \\
\hline & II & $\begin{array}{l}\text { When others help me, I reflect on how and what I achieved in learning and in what areas and how I } \\
\text { should improve. }\end{array}$ \\
\hline & III & $\begin{array}{l}\text { I autonomously reflect on how and what I achieved in learning; others help me to plan in what } \\
\text { areas and how I should improve. }\end{array}$ \\
\hline & IV & $\begin{array}{l}\text { I autonomously reflect on how and what I achieved in learning and plan in what areas and how I } \\
\text { can improve. }\end{array}$ \\
\hline
\end{tabular}

The questionnaires were completed at two moments—-before (pre-test) and after the outdoor experience (post-test)—like other similar studies [12,74]. 


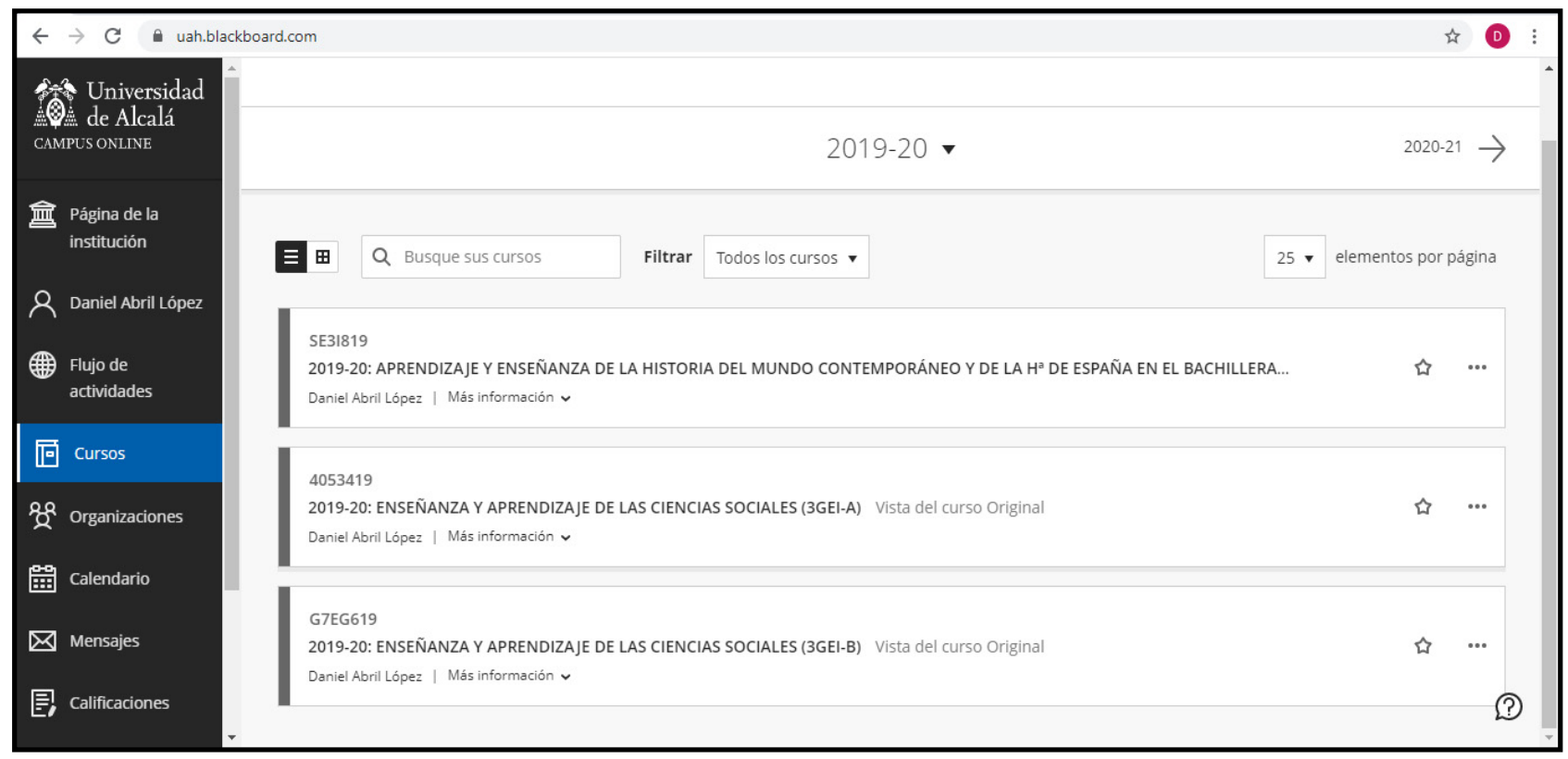

Figure 2. Blackboard Learn from teacher trainer Daniel Abril-López (2019-2020 academic year).

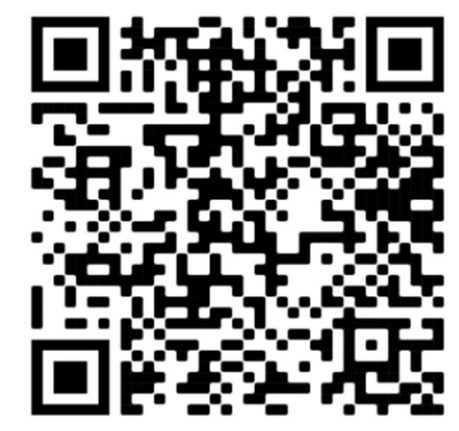

Figure 3. QR code of the category system by progression level (pre-test-post-test).

\section{Methodological Proposal}

The present experience was carried out as part of the subject Teaching and Learning of Social Sciences of the Degree in Early Childhood Education (3rd year) at the University of Alcalá (Spain) during three academic years: 2017-2018; 2018-2019; and 2019-2020.

\subsection{Phase 1: Before the Field Trip}

The Guadalajara Museum deals with 16 different themes, interesting from the point of view of teaching social sciences: Hunting, fishing, and gathering; beekeeping; cattle raising; farming; metallurgy; textiles; games and toys; painting; money; jewelry; goldsmithing and pottery; sculpture; weapons; death; religion; and traditions.

The teacher worked in the classroom, through Blackboard Learn, with the ECPT before the field trip. First, a debate was held to obtain prior knowledge on three main pillars, including competences, museums, and e/m-learning, through different questions: What are competencies? What is the learning to learn competence? Why is it important? Are museums suitable spaces for acquiring skills and why? How can we work, in these institutions, on activities for early childhood education and applied e/m-learning?

Afterwards, the general characteristics of the teaching experience were explained, including the e/m-learning tools (Blackboard Learn and websites) and information related to the museum of Guadalajara [75-77]. 
Finally, the students organized themselves into working groups of four-five members. Each group selected one of the 16 themes to investigate in the museum based on data collection and collaborative and autonomous work.

\subsection{Phase 2: Museum Field Trip}

The Guadalajara Museum is the oldest provincial museum in Spain, inaugurated in 1838. It has a collection of interrelated archeology, ethnology, and fine arts material. Since 1973, its headquarters has been the Palacio del Infantado (Figure 4), which is a late Gothic building built around 1480 by the mandate of the 2nd Duke of Infantado [77].

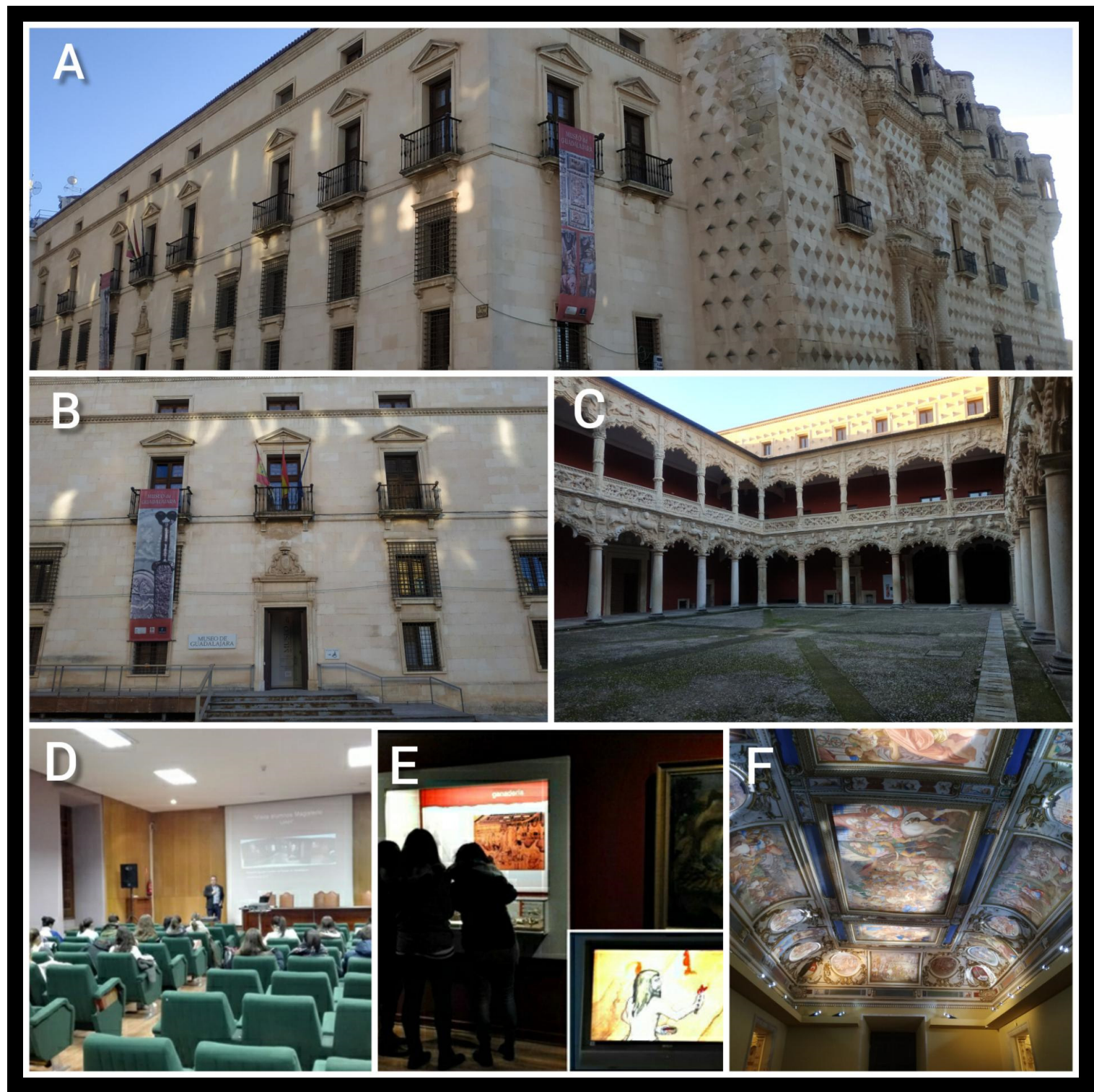

Figure 4. Museum of Guadalajara. (A) Facade of the Infantado Palace. (B) Access door. (C) Courtyard of the Lions. (D) Talk about museography. (E) "Transits" room (lower right frame: Video, in another room, on the cave paintings). (F) Room of "El Palacio del Infantado: Mendoza and power in Castilla".

The visit was guided with the help of museum monitors and accompanied by the support of the director of the institution in matters of museography (Figure 4D). The museum has different rooms: Two of them are dedicated to temporary exhibitions and another two are large rooms ("Transits" room and "El Palacio" room) used for permanent exhibitions on which this experience is centered. The "Transits" room (Figure 4E) proposes 
an anthropological journey focused on the theme of life-death-religiosity from prehistory to the 20th century [75]. The second permanent exhibition or room (Figure 4F), named "The Palace of the Infantado: the Mendoza and the power in Castilla", interprets the property (oil paintings, frescoes, sculptures, etc.) and the lineage that have been present there since the end of the 15th century [76].

We consider the Museum of Guadalajara to be very important for the early childhood education stage (3-6 years), because it is a large space; it captures the visitor's attention; and it contains very diverse and appropriate materials, including paintings, sculptures, tools, etc., to explain social relations, both past and present, and present differences and conclusions. These museum experiences have already been pointed out by several authors who have worked on this educational stage, through the adequate adaptation of didactic and motivational activities by the ECPT [59-63].

During the guided visit, the ECPT freely observed the exhibition, collecting field data on the museum that they believed were relevant to answering the research question posed. To complement this free observation, the ECPT was offered a questionnaire designed by the teacher (guided observation) and accessed by a QR code (Figure 5). The Likert-type questionnaire, with values ranging from 1 to 5 (from least agreement to most agreement), allowed various questions about the museum, both in terms of form and content (facilities, Information and Communication Technology, Learning and Knowledge Technologies, didactic workshops, socio-critical discourse, contents, interdisciplinarity, didactic documentation, and the relationship between activities and the museum), to be assessed.

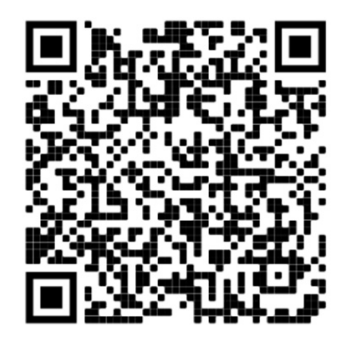

Figure 5. QR code for accessing the questionnaire about the visit to the Museum of Guadalajara.

\subsection{Phase 3: After the Field Trip}

Once in the classroom, the ECPT shared their outdoor experience with the whole class. The data collected were shared, in addition to the evaluations made from the Likert scale. Some of the conclusions and results obtained regarding the museum as having educational potential are as follows:

- At a general level: The museum presents the contents organized at a diachronic level, which favors comparative learning between the past and the present.

- At a specific level: In relation to the 16 topics discussed, different issues, potentialities, and weaknesses of each topic were assessed as an educational resource for early childhood education.

Based on this analysis, a total of 58 teaching proposals adapted to early childhood education were designed and presented. The activities were presented orally by each team. We highlight some activities linked, above all, to the promotion of the world of competence: Textiles and clothing (linguistic communication); money and economic practices (mathematics); beekeeping and nature (knowledge and interaction with the environment); pottery and professions (information and digital); hunting, fishing, and gathering: yesterday and today (social and civic); traditions and heritage, such as Las Botargas (cultural and artistic); sowing and the Mediterranean diet (learning to learn); metallurgical artifacts and inequalities (autonomy and personal initiative); and the game of marbles (emotional). 
Teaching activities were evaluated with a rubric organized into four complexity levels and six variables based on the main educational elements for the teaching-learning process (Table A1). This rubric was validated during the pilot experience of the course 20172018 [78]. As we have justified, our main data analysis involved the ECPT's self-perception, but we also considered analyses on the teaching activities designed by the ECPT, in order to obtain a more holistic view of the teaching and learning process. The rubric results were high: 30\% for the II-III level; 55\% for III-IV; and just 15\% for the II level.

Finally, the ECPT carried out the post-test with the same categories or questions as those in the pre-test.

\section{Results}

The results shown here correspond to the pre- and post-test questionnaires. The four levels of complexity, based on the European Commission about the learning to learn competence [68], appear in the QR code (see Figure 3): I, first steps; II, going in the right direction; III, close to the target; and IV, full competence acquired. The results do not show the main differences in terms of the percentage depending on the academic course, group of students, or theme. We realize that the figures are very homogeneous.

As we can see in Table 2, the ECPT considers that they exhibit level III for the four assessed dimensions (approximately 50\%), close to the desirable level: 1, $146=56.59 \%$; 2, $169=65.50 \% ; 3,147=56.98 \%$; and 4, $128=49.61 \%$. Dimension 2 (What I learn) is the one with the highest level of the four dimensions. Level IV (competence acquired), meanwhile, was the second most chosen level by the ECPT in three dimensions: 1, $52=20.16 \% ; 2,52=20.16 \%$; and 3, $49=18.99 \%$. In dimension 4 , level IV was the third most chosen level: $30=11.63 \%$ (Table 2 ).

Table 2. Acquiring learning to learn competence (pre-test) by dimension and level of progression $(n=258)$.

\begin{tabular}{ccccc}
\hline Learning to Learn-Before & LEVEL I & LEVEL II & LEVEL III & LEVEL IV \\
\hline 1. Why I learn & 29 & 31 & 146 & 52 \\
2. What I learn & 9 & 28 & 169 & 52 \\
3. How I learn & 23 & 39 & 147 & 49 \\
4. I reflect on my progress & 27 & 73 & 128 & 30 \\
\hline
\end{tabular}

In relation to the lower levels of I and II, their sum is below $40 \%$ of the total for the four levels. The maximum value of level I corresponds to the first dimension $(29=11.24 \%)$, while in level II, it corresponds to dimension four (I reflect on my progress), with a value of $73=28.29 \%$.

The results of the post-test are presented in Table 3. The highest results of the four dimensions can be observed for level IV or the reference level. Level I is practically non-existent in the second and third dimensions, with $0.78 \%(n=2)$ and $2.32 \%(n=6)$, respectively; the other two variables do not reach $7 \%$ of the total responses. Level II also shows a large decrease (below 10\%), being between $5.81 \%(n=15)$ and $9.69 \%(n=25)$ for the first and third variables.

Table 3. Acquiring learning to learn competence (post-test) by dimension and level of progression $(\mathrm{n}=258)$.

\begin{tabular}{ccccc}
\hline Learning to Learn-After & LEVEL I & LEVEL II & LEVEL III & LEVEL IV \\
\hline 1. Why I learn & 18 & 15 & 57 & 168 \\
2. What I learn & 2 & 21 & 91 & 144 \\
3. How I learn & 6 & 25 & 72 & 155 \\
4. I reflect on my progress & 14 & 22 & 29 & 193 \\
\hline
\end{tabular}


Level III (close to the target) was the second most chosen by the students for the four variables: $1,57=22.09 \% ; 2,91=35.27 \% ; 3,72=27.91 \%$; and $4,29=11.24 \%$. It surpassed the data of the previous levels (I and II). Finally, level IV obtained the best scores, since the evolution with respect to the pre-test is very noticeable for the four variables, mainly the last of them: $1,168=65.12 \% ; 2,144=55.81 \% ; 3,155=60.08 \%$; and $4,193=74.81 \%$. The most prominent dimension is 4 (I reflect on my progress).

If we compare the pre- and post-test results, for levels I and II of the four dimensions, percentage variation is observed, especially for dimension 4 of level II $(28.29 \%$ versus $8.53 \%=-19.76 \%)$. At level IV, an increase can be observed for all dimensions: 1 , $65.12 \%$ versus $20.16 \%=+44.96 \% ; 2,55.81 \%$ versus $20.16 \%=+35.65 \% ; 3,60.08 \%$ versus $18.99 \%=+41.09 \%$; and $4,74.80 \%$ versus $11.63 \%=+63.17 \%$.

These self-perception data show the progress of the acquisition of competence after the experience carried out.

\section{Discussion}

Developing a shared understanding of what learning to learn means in practice may be particularly challenging [79]. The acquisition of this competence can have a triple purpose: "Firstly, it shows how attitudes can be explicitly incorporated into learning outcomes. Secondly, it demonstrates how the level to which a competence has been acquired can be assessed with levels indicating each learner's progress. Thirdly, the learning outcomes are written from the student's perspective to help them monitor their progress with their teachers" [68] (p. 14).

In this experience, the system of categories by level of progression on the competence learning to learn showed visible differences between the pre-test phase and the post-test phase for the four dimensions [68] (p. 15), as can be seen in Figures 6-9: "1. Why I learn (attitude towards learning and willingness to learn); 2. What I learn (setting objectives and planning activities); 3. How I learn (organized and targeted learning activities); and 4. I reflect on my progress (reflection on learning activities and outcomes and self-assessment)".

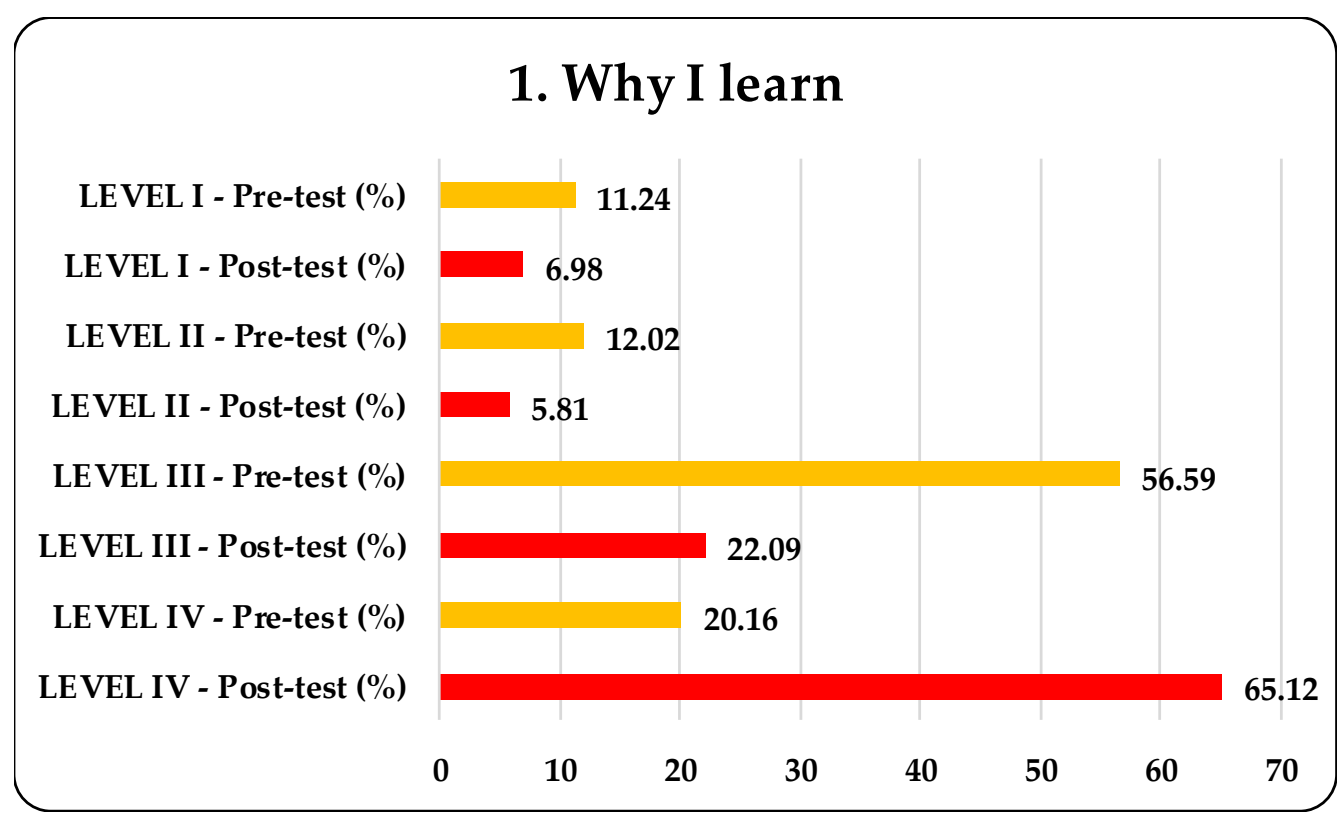

Figure 6. Levels of achievement of the first dimension: Why I learn. 


\section{What I learn}

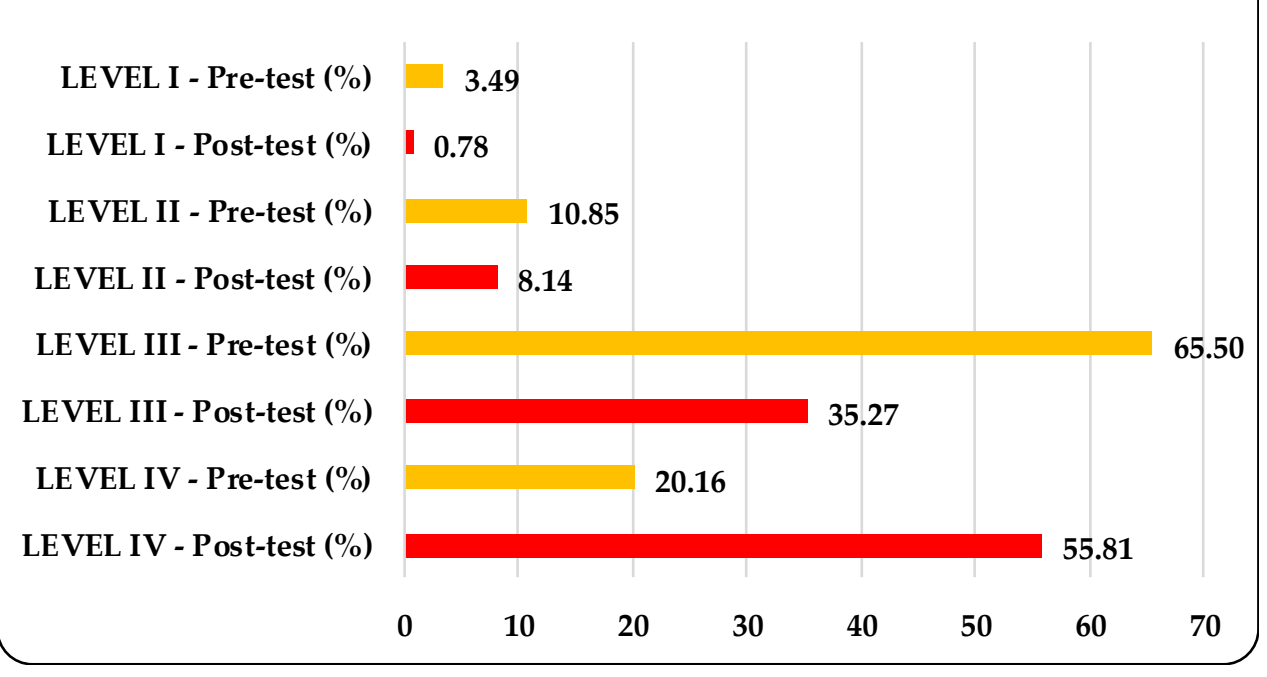

Figure 7. Levels of achievement of the second dimension: Why I learn (\%).

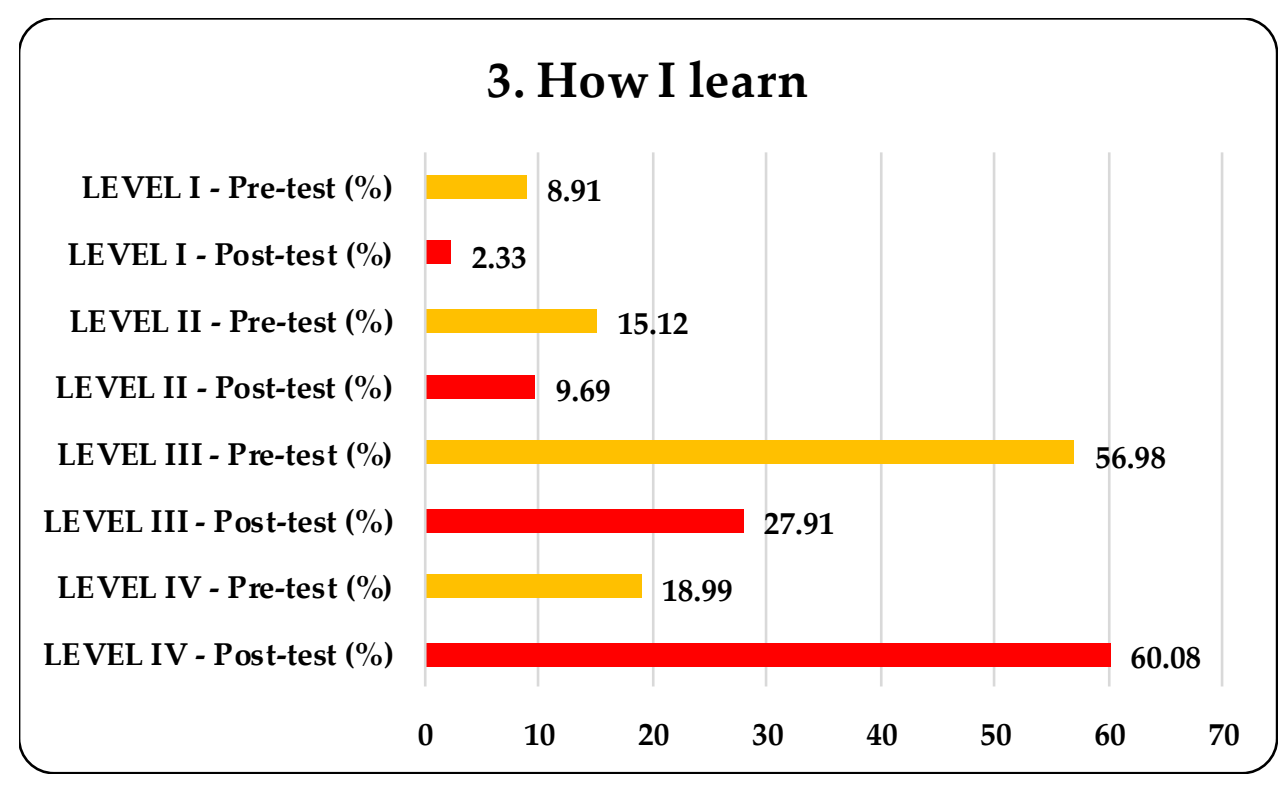

Figure 8. Levels of achievement of the third dimension: How I learn (\%).

In general, in relation to the four dimensions that were analyzed, after the outdoor experience, the ECPT reached levels III and IV in the post-test. This translates-along with the results of the rubrics for the evaluation of the students-into an improvement in self-confidence, teamwork and collaboration, enthusiasm, responsibility, planning, new challenges, completion of tasks on time, and successful goals.

Numerical and percentage data were reinforced with descriptive statistic measures, including the mean or average $(\mu)$, standard deviation $(\sigma)$, and coefficient of variation $(\mathrm{CV})$. These parameters contributed very significant figures. Level III (pre-test) and level IV (post-test) prevailed in all four dimensions (Table 4).

For the first three questions, it can be observed that most of the ECPT's have increased half a level in the post-test, and increased a full level for the fourth question. As the dispersions are similar in the pre-test and post-test data, the graph shifts as a block or homogeneously. 


\section{I reflect on my progress}

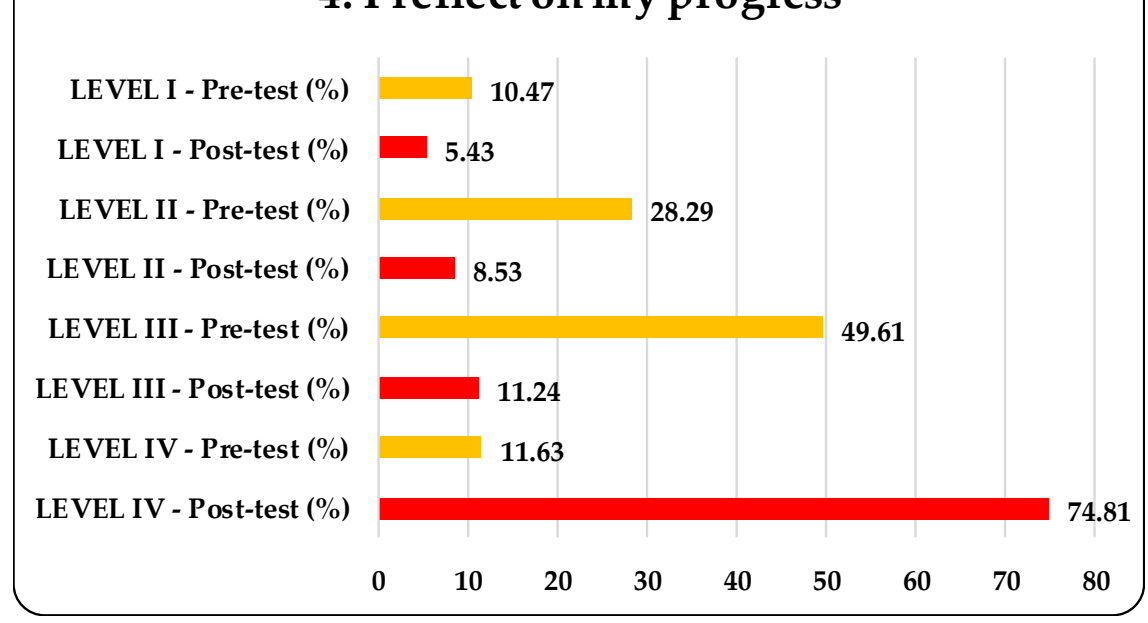

Figure 9. Levels of achievement of the fourth dimension: I reflect on my progress (\%).

Table 4. Acquiring learning to learn competence (pre-test-post-test): Descriptive statistics.

\begin{tabular}{ccccccc}
\hline \multirow{2}{*}{ Learning to Learn } & \multicolumn{2}{c}{$\mu$} & \multicolumn{2}{c}{$\boldsymbol{\sigma}$} & \multicolumn{2}{c}{ CV (\%) } \\
\cline { 2 - 7 } & Pre-Test & Pos-Test & Pre-Test & Post-Test & Pre-test & Post-Test \\
\hline 1. Why I learn & 2.9 & 3.5 & 0.9 & 0.9 & 30 & 26 \\
2. What I learn & 3.0 & 3.5 & 0.7 & 0.7 & 22 & 20 \\
3. How I learn & 2.9 & 3.5 & 0.8 & 0.8 & 29 & 22 \\
4. I reflect on my progress & 2.6 & 3.6 & 0.8 & 0.9 & 31 & 24 \\
\hline
\end{tabular}

In order to confirm this statement, we calculated the coefficient of variation. This allows one to learn whether the dispersions are the same or different when the standard deviation is the same. The smaller the coefficient of variation, the more concentrated the data will be around the mean. In our research, the CV is less than or equal to $30 \%$, that is, the data set is homogeneous, and the arithmetic mean is representative of the data set.

Furthermore, we highlight two dimensions that exhibit higher values: In the pre-test, dimension 2 "What I learn", and in the post-test, dimension 4 "reflect on my progress". It seems that what the student attributes the greatest importance from an educational perspective is the acquisition of content. This leads us to think that the ECPT's relate content to learning. Similarly, in the study by Maynard and Waters [80], they observed this vision of teaching in practicing early childhood education teachers, when they designed outdoor activities, giving greater importance to factual content. However, after the experience, the ECPT attaches greater importance to reflecting on their own learning process in an autonomous way. This dimension is related to metacognition, being a transversal competence of the curriculum [79].

On the other hand, in relation to the academic performance of the ECPT, the analysis of the museum as a resource, and the design and exhibition of its teaching proposals, we highlight the autonomous and cooperative work that they developed throughout the experience. Likewise, after evaluating their educational proposals with the rubric, we can verify that they tend to lean towards reference level III-IV. These results complement the results obtained with the pre- and post-test of their self-perception, or what they declare with what we as research teachers observe after carrying out the experience.

\section{Conclusions}

In the early childhood education stage, the teaching of social sciences in Spain is fundamental, from the perspective of knowledge of the environment, as reflected in the state and autonomous educational curriculum. Several authors have emphasized this 
issue [56-61], but they have not focused on the acquisition of educational skills, with some exceptions through certain activities and projects [23-25].

At a methodological level, we defend the use of an educational model for the teaching of social sciences which allows us to work with socially relevant problems and a globalized approach [81]. Consequently, this innovative experience has been developed with the ECPT's through these educational principles, which we believe are references, so that they can reproduce it with their students in the future.

In this research, we highlight, on one hand, the importance of promoting innovative educational experiences such as the one we have described and, on the other hand, the results of this research. As teacher educators, based on the results obtained in this experience, we highlight three important educational teaching implications.

First is the importance of outdoor education and the use of e/m-learning tools for the acquisition of ECPT competencies. The students from the field trip in the museum improved the learning to learn competence, as a basis of learning for life [34]. The statistical data of our research contrasted the evolution from level III (pre-test) to IV (post-test) in relation to the acquisition of the learning to learn competence. Ultimately, the mean or average is representative and homogeneous, with a distribution that shifts in a similar or block way.

Second, we highlight the need to design field trips with an inquiry learning approach, in order to improve the scientific knowledge and skills required to solve social problems. Therefore, not all field trips have the same implication in the teaching-learning processes, since, in many cases, they are a reproduction of the indoor lesson [80]. Even though there are several investigations with ECPT focused on the design of field trips [56-61], in our case, we focused on the field of competence. In this sense, we achieved results where there is progression in the teaching and learning processes, evidenced in both the category system and the rubric.

Third, museums are becoming increasingly important in civic education [34]. For this reason, it is necessary that they be adapted to different educational levels, with the stage of early childhood education being one of the least renewed stages in museums [62,63]. We obtained this observation from the analysis carried out in the Guadalajara Museum as an educational resource for early childhood education. The museum is not adapted to this stage, as shown by the data obtained from the different questions of the questionnaire (see Figure 5).

The technological resources that it uses are scarce and not very varied (videos, projections, and QR codes). Likewise, it does not present resources that favor manipulation or interaction with the visitor, or that invite the exhibition, all of which are relevant issues for learning in the early childhood education stage. However, the museum presents other interesting educational possibilities for children in early childhood education, such as diversity of the material register, from a diachronic evolution that benefits past-present (and future) comparatives. The museum's message contains interesting socio-critical characteristics for teaching, but reflection on and searches for collective improvements should be focused on.

\section{Limitations of the Study}

This study is based on an approach of the level of achievement of the learning to learn competence from ECPT's perception and complemented these results with their teaching activities. The study could be enhanced by the implementation of other assessment instruments by the teachers and completing it with a full data analysis, closing the circle, and conducting a 360 analysis of the data collected.

Author Contributions: Conceptualization, D.A.-L. and H.M.-M.; methodology, D.A.-L.; software, M.D.L.C.; validation, D.A.-L.; formal analysis, D.A.-L.; investigation, D.A.-L.; resources, D.A.-L., M.d.C.M.-M., H.M.-M. and M.D.L.C.; data curation, D.A.-L.; writing-original draft preparation, D.A.-L. and H.M.-M.; writing-review and editing, M.d.C.M.-M., H.M.-M. and M.D.L.C.; visualization, D.A.-L. and H.M.-M.; supervision, M.d.C.M.-M., H.M.-M. and M.D.L.C.; project administration, 
D.A.-L.; funding acquisition, D.A.-L. and M.d.C.M.-M. All authors have read and agreed to the published version of the manuscript.

Funding: This work was developed within the framework of the following funded teaching innovation projects: The Museum as a teaching-learning space: design of significant educational activities for Early Childhood Education (UAH/EV916), The Museum of Early Childhood Education: design, development and exhibition of significant didactic activities (UAH/EV1049), and Art to Dream: a SL project in Early Childhood Education from the didactics of Art, Social Sciences and Mathematics (UAH/EV1113) (University of Alcalá). In addition, it had the support of the I + D + i EPITEC project: Heritage education for the territorial and emotional intelligence of citizens. Analysis of good practices, design and intervention in compulsory education (EDU2015-67953-P) (Ministry of Science, Innovation and Universities/FEDER).

Data Availability Statement: Not Applicable, the study does not report any data.

Acknowledgments: The advice, guidance, and predisposition of the director of the Museum of Guadalajara, Fernando Aguado Díaz, was fundamental for the development of this teaching experience. In addition, lecturer María Teresa Rodríguez Laguna (University of Alcalá) advised us to obtain the statistical data.

Conflicts of Interest: The authors declare no conflict of interest.

\section{Appendix A}

Table A1. Rubric for evaluating teaching activities.

\begin{tabular}{|c|c|c|}
\hline Variables & Level & Descriptors \\
\hline \multirow{4}{*}{ 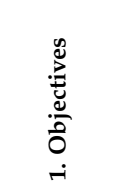 } & I & Less than three, and no link to the evaluation. \\
\hline & II & Repeated repetition of verbs. Relationship with the contents. \\
\hline & III & The contextualization of the students is taken into account, and their integral progress. \\
\hline & IV & Links between past, present, and future. "Change the world". \\
\hline \multirow{4}{*}{ 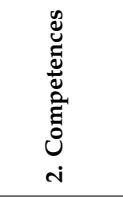 } & I & They are not mentioned. \\
\hline & II & Only its name is included. \\
\hline & III & Two or three competences covered are detailed. \\
\hline & IV & The totality of competencies is detailed, as is fundamental in a changing world. \\
\hline \multirow{4}{*}{ 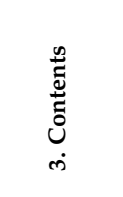 } & I & The tripartite division is not established and the tasks are not broken down. \\
\hline & II & There are no tasks before or after the visit. \\
\hline & III & Consistent information: From simplicity to complexity. \\
\hline & IV & Contents with problems. Development over time. \\
\hline \multirow{4}{*}{ 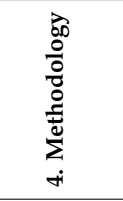 } & I & The methodology is not included. \\
\hline & II & Undeveloped teaching-learning model. Disciplinary activity. \\
\hline & III & Methodology explained. Multidisciplinary activity. \\
\hline & IV & Appearance of didactic methods. Interdisciplinary activity. \\
\hline \multirow{4}{*}{ 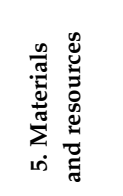 } & I & They are not related to the development of tasks. \\
\hline & II & Lack of ICT/LKT resources. \\
\hline & III & Broken down over the sessions before, during, and after the museum visit. \\
\hline & IV & Exhibition with e-learning, and interactions with the rest of the students (feedback). \\
\hline \multirow{4}{*}{ 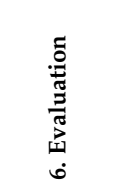 } & I & There is no connection to other elements of the curriculum. \\
\hline & II & Mention of the instruments. \\
\hline & III & Appearance of rubrics. \\
\hline & IV & Related to the objectives, skills, and content. \\
\hline
\end{tabular}




\section{References}

1. Morin, E. Introduction à la Pensée Complexe; ESF: Paris, France, 1990.

2. Hodson, D. Learning science, learning about science, doing science: Different goals demand different learning methods. Int. J. Sci. Edu. 2014, 36, 2534-2553. [CrossRef]

3. Morón-Monge, H.; Morón-Monge, M.C.; Abril-López, D.; Daza Navarro, M.P. An approach to prospective primary school teachers' concept of environment and biodiversity through their design of educational itineraries: Validation of an evaluation rubric. Sustainability 2020, 12, 5553. [CrossRef]

4. Daza Navarro, M.; Morón-Monge, H.; Daza Navarro, M.P. El trabajo por proyectos en educación secundaria obligatoria: ‘Tres visions, tres generaciones'. Rev. Andin. Educ. 2020, 3, 32-40. [CrossRef]

5. Organisation for Economic Co-Operation and Development (OECD). PISA 2018 Results (Volume VI): Are Students Ready to Thrive in an Interconnected World? OECD Publishing: Paris, France, 2020. [CrossRef]

6. Romero Ariza, M. El aprendizaje experiencial y las nuevas demandas formativas. Antropol. Exp. 2010, 10, 89-110. Available online: https:/ / revistaselectronicas.ujaen.es/index.php/rae/article/view/1970/1718 (accessed on 10 October 2020).

7. Publications Office of the European Union. 2006. Recommendation 2006/962/EC, of 18 December 2006, of the European Parliament and of the Council on key competences, for lifelone learning. Off. J. Eur. Un. 2006, L394, 10-18. Available online: https:/ / eur-lex.europa.eu/legal-content/EN/TXT/PDF/?uri=CELEX:32006H0962\&from=EN (accessed on 2 November 2020).

8. Pérez-Pérez, C.; García, F.J.; Vázquez, V.; García, E.; Riquelme, V. The 'Learning to Learn' competence in bachelor's degrees. Aula Abierta 2020, 49, 316-323. [CrossRef]

9. Rogers, Y.; Price, S.; Randell, C.; Stanton, D.; Weal, M.; Fitzpatrick, G. Ubi-learning integrates indoor and outdoor experiences. Commun. ACM 2005, 48, 55-59. [CrossRef]

10. Chen, C.-C.; Huang, T.-C. Learning in a u-Museum: Developing a context-aware ubiquitous learning environment. Comput. Edu. 2012, 59, 873-883. [CrossRef]

11. Pierroux, P.; Krange, I.; Sem, I. Bridging contexts and interpretations: Mobile blogging on art museum field trips. MedieKultur 2011, 27, 30-47. [CrossRef]

12. Solís-Espallargas, C.; Morón-Monge, H. How to improve sustainability competences of teacher training? Inquiring the prior knowledge on climate change in primary school students. Sustainability 2020, 12, 6486. [CrossRef]

13. Loynes, C.; Michie, D.; Smith, C. Justifying outdoor education in the formal and informal curriculum. In A Guide for Outdoor Educators in Scotland; Higgins, P., Loynes, C., Crowther, N., Eds.; Adventure Education: Penrith, UK, 1997; pp. 15-21.

14. Lee, H.; Stern, M.J.; Powell, R.B. Do pre-visit preparation and post-visit activities improve student outcomes on field trips? Environ. Edu. Res. 2020, 26, 989-1007. [CrossRef]

15. Organisation For Economic Co-Operation and Development (OECD). The Definition and Selection of Key Competences. Available online: https: / /www.oecd.org/pisa/35070367.pdf (accessed on 5 December 2020).

16. Cuban, L. Curriculum stability and change. In Handbook of Research on Curriculum: A Project of the American Educational Research Association; Jackson, P.W., Ed.; Macmillan: New York, NY, USA, 1992; pp. 216-247.

17. Lavrenteva, E.; Lily, O.-B. The treatment of culture in the foreign language curriculum: An analysis of national curriculum documents. J. Curr. Stud. 2015, 47, 653-684. [CrossRef]

18. Ministerio de la Presidencia. Orden ECD/65/2015, de 21 de enero, por la que se describen las relaciones entre las competencias, los contenidos y los criterios de evaluación de la educación primaria, la educación secundaria obligatoria y el bachillerato. $B O E$ 2015, 25, 6986-7003. Available online: https://www.boe.es/boe/dias/2015/01/29/pdfs/BOE-A-2015-738.pdf (accessed on 10 September 2020).

19. Muñoz, A.; Bocanegra, I.; Curquejo, M.I.; García, A.; Gómez, A.; Mateos, A.; Mulero, C.; Párraga, M.; Salas, A. Competencias básicas en educación infantil. Clave XXI 2010, 2. Available online: http://clave21.ieszaframagon.com/files/articulos/ CompetenciasEI_0.pdf (accessed on 17 September 2020).

20. Domínguez, R.; Edward, S.S. Curriculum-based measurement and the evaluation of reading skills of Spanish-speaking English language learners in bilingual education classrooms. Sch. Psyc. Rev. 2006, 35, 356-369. [CrossRef]

21. Departamento de Presidencia. Decreto 67/2007, de 29 May 2007, por el que se establece y ordena el currículo del segundo ciclo de la educación infantil en la comunidad autónoma de Castilla-La Mancha. DOCM 2007, 116 (1 de junio de 2007), 14743-14759. Available online: http:/ / www.educa.jccm.es/es/sistema-educativo/decretos-curriculo/normativa-vigente-educacion-infantil (accessed on 8 September 2020).

22. Departamento de Presidencia. Decreto 88/2009, de 07 July 2009, por el que se determinan los contenidos educativos del primer ciclo de la Educación Infantil y se establecen los requisitos básicos que deben cumplir los centros que lo impartan en la comunidad autónoma de Castilla-La Mancha. BOCM 2009, 133 (10 de julio de 2009), 30037-30062.

23. Muñoz, A. El Desarrollo de las Competencias Básicas en Educación Infantil; MAD-Eduforma: Alcalá de Guadaíra, Spain, 2009.

24. Vieites, M.C. Programación por Competencias en Educación Infantil. Del Proyecto Educativo al Desarrollo Integral del Alumnado; Ideaspropias Editorial: Vigo, Spain, 2009.

25. Ureña, M. Competencias y proyectos en Educación Infantil: Hacia una educación holística. Calanda 2013, 8, 22-31. Available online: https: / / sede.educacion.gob.es/publiventa/descarga.action?f_codigo_agc=15953 (accessed on 21 October 2020).

26. Knowles, M.S. Fostering competence in self-directed learning. In Learning to Learn Across the Lifespan; Smith, R.M., Ed.; Jossey-Bass: San Francisco, CA, USA, 1990; pp. 123-136. 
27. Hautamäki, J.; Arinen, P.; Eronen, S.; Hautamäki, A.; Kupiainen, S.; Lindblom, B.; Niemivirta, M.; Pakaslahti, L.; Rantanen, P.; Scheinen, P. Assessing Learning-to-learn. A framework; University of Helsinki: Helsinki, Finland, 2002.

28. Drăghicescu, L.M.; Cristeab, S.; Petrescua, A.-M.; Gorghiuc, G.; Gorghiu, L.M. The learning to learn competence-Guarantor of personal development. Proced. Soc. Behav. Sci. 2015, 191, 2487-2493. [CrossRef]

29. Vázquez, S. TIC y competencia aprender a aprender. Rev. Padres Madres J. Parent. Teach. 2009, 326, 38-39. Available online: https:/ / revistas.comillas.edu/index.php/padresymaestros/article/view/1325/1132 (accessed on 3 December 2020).

30. Jornet Meliá, J.M.; García-Bellido, R.; González-Such, J. Evaluar la competencia aprender a aprender: Una propuesta metodológica. Profesorado 2012, 16, 103-123. Available online: https: / www.ugr.es/ \{\}recfpro/rev161ART7.pdf (accessed on 30 November 2020).

31. Department for Education and Skills. Learning Outside the Classroom. Manifesto. Available online: http://www.lotc.org.uk/ wp-content/uploads/2011/03/G1.-LOtC-Manifesto.pdf (accessed on 15 October 2020).

32. Wilson, R.A. Environmental Education at The Early Childhood Level; North American Association for Environmental Education: Washington, DC, USA, 1994.

33. Cañal, P. La alfabetización científica en la infancia. Aula Infantil 2006, 33, 5-9.

34. Akamca, G.O.; Yildirim, R.G.; Ellez, A.M. An alternative educational method in early childhood: Museum education. Edu. Res. Rev. 2017, 12, 688-694. [CrossRef]

35. Dillon, J.; Rickinson, M.; Teamey, K.; Morris, M.; Choi, M.Y.; Sanders, D.; Benefield, P. The value of outdoor learning: Evidence from research in the UK and elsewhere. Sch. Sci. Rev. 2006, 87, 107-111.

36. Anderson, D.; Piscitelli, B.; Everett, M. Competing agendas: Young children's museum field trips. Curator Mus. J. 2008, 51, 253-273. [CrossRef]

37. Delgado, J.E.; Alario, M.T. La interacción fuera del aula: Itinerarios, salidas y paseos. Tabanque 1994, 9, 155-178. Available online: https: / / dialnet.unirioja.es/revista/1396/A/1994 (accessed on 13 December 2020).

38. Cantó, J.; Hurtado, A.; Vilches, A. Una propuesta de actividades "fuera del aula" sobre sostenibilidad para la formación del profesorado. Enseñanza Cienc. 2013, 638-642. Available online: https://ddd.uab.cat/pub/edlc/edlc_a2013nExtra/edlc_a201 3nExtrap638.pdf (accessed on 18 November 2020).

39. Álvarez, D.; Vázquez, W.; Rodríguez, L.A. La salida de campo, una posibilidad en la formación inicial docente. Didáctica Cienc. Exp. Soc. 2016, 31, 61-78. [CrossRef]

40. Costillo, E.; Borrachero, A.B.; Villalobos, A.M.; Mellado, V.; Sánchez, J. Utilización de la modelización para trabajar salidas al medio natural en profesores en formación de educación secundaria. Bio Grafía 2014, 7, 165-175. [CrossRef]

41. Fernández-Ferrer, G.; González-García, F. Salidas de campo y desarrollo competencial. Enseñanza Cienc. Tierra 2017, 25 , $295-301$. Available online: https:/ /www.raco.cat/index.php/ECT/article/view/330134/420944 (accessed on 8 December 2020).

42. Mateo, M.R. Las salidas de campo en el medio rural. Análisis de las investigaciones presentadas a congresos del grupo de trabajo de didáctica de la geografía de la AGE y de la APG (1988-2016). In La Reconfiguración del Medio Rural en la Sociedad de la Información. Nuevos Desafíos en la Educación Geográfica; Macía, X., Armas, F., Rodríguez, F., Eds.; Andavira: Santiago de Compostela, Spain, 2019; pp. 1279-1292. Available online: http://didacticageografia.age-geografia.es/docs/Publicaciones/2019_IX_Congreso_Iberico.pdf (accessed on 13 October 2020).

43. Robinson, V. Problem-Based Methodology: Research for the Improvement of Practice; Emerald Bingley Publishing Limited: Bingley, UK, 1993.

44. Jauregui, P.A.; Goienetxe, R.M.A.; Vidales, K.B. El aprendizaje basado en la indagación en la enseñanza secundaria. Rev. Investig. Educ. 2018, 36, 109-124. [CrossRef]

45. Gómez, C.J.; Rodríguez, R.A. Aprender a enseñar ciencias sociales con métodos de indagación. Los estudios de casos en la formación del profesorado. REDU 2014, 12, 307-325. Available online: https:/ / polipapers.upv.es/index.php/REDU/article/ view /5651/5643 (accessed on 5 December 2020). [CrossRef]

46. Fernández-Cabezas, M. Aprendizaje basado en proyectos en el ámbito universitario: Una experiencia de innovación metodológica en educación. Int. J. Develop. Educ. Psych. INFAD 2017, 2, 269-278. [CrossRef]

47. Bates, A.W. Technology, E-Learning and Distance Education, 2nd ed.; Routledge: Abingdon, UK, 2005.

48. Lan, Y.-F.; Tsai, P.-W.; Yang, S.-H.; Hung, C.-L. Comparing the social knowledge construction behavioral patterns of problem-based online asynchronous discussion in e/m-learning environments. Comp. Edu. 2012, 59, 1122-1135. [CrossRef]

49. Morales Agudo, J. E-Museum. Una Investigación Sobre Tecnologías Para "Aprender A Aprender" En Educación Plástica Y Visual. Ph.D. Thesis, Universidad de Zaragoza, Zaragoza, Spain, 2015.

50. Rivero, M.P. Didáctica de las Ciencias Sociales para Educación Infantil; Mira Editores: Zaragoza, Spain, 2011.

51. Aranda, A.M. Didáctica de las Ciencias Sociales en Educación Infantil; Síntesis: Madrid, Spain, 2016.

52. Puig, M.; Rodríguez-Marín, F. La enseñanza del entorno en Educación Infantil. Proyectos y rincones; Pirámide: Madrid, Spain, 2018.

53. Cuenca, J.M.; Estepa, J.; Jiménez, R.; Martín, M.; Wamba, A.M. Patrimonio y Educación: Quince años de investigación. In La Educación Patrimonial en la Escuela y el Museo: Investigación y Experiencias; Estepa, J., Ed.; Universidad de Huelva: Huelva, Spain, 2013; pp. 13-24.

54. Cáceres, M.M.; Cruz, I.L.; Morón, H.; Ferreras, M. La educación patrimonial en los museos. Análisis de materiales didácticos. Clío 2014, 40. Available online: http:/ / clio.rediris.es/n40/articulos/martincaceres.pdf (accessed on 20 January 2021).

55. Boj, I. La didáctica de la prehistoria como instrumento de transformación social. Íber 2001, 29, 19-26. 
56. Pérez Melgar, M.; Morón Monge, H. El itinerario didáctico como herramienta para la activación patrimonial: Una experiencia docente desde el Parque María Luisa. Campo Abierto 2016, 35, 83-94. Available online: https://mascvuex.unex.es/revistas/index. php/campoabierto/article/view/2750/pdf_29 (accessed on 12 December 2020).

57. León, E. Hacia el Aprendizaje Significativo Fuera de la Escuela; Final Degree Proyect; Universidad de Sevilla: Sevilla, Spain, 2015.

58. Bardavio, A.; Mañé, S.; Pizarro, J.; Vila, M. Una experiència integrada d'educació i investigació prehistòrica. El Camp d'Aprenentatge de la Noguera. Treb. d'Arqueologia 2013, 19, 105-120. [CrossRef]

59. De los Reyes, J.L. Del patrimonio cultural al museo infantil. Tarbiya 2009, 40, 107-124. Available online: https:/ / revistas.uam.es/ tarbiya/article/view/7186/7512 (accessed on 11 October 2020).

60. Escribano-Miralles, A.; Molina, S. La importancia de salidas escolares y museos en la enseñanza de las ciencias sociales en Educación Infantil. Análisis de un caso a partir del modelo CIPP. Clío. Hist. Hist. Teach. 2015, 41. Available online: http:/ / clio.rediris.es/n41/articulos/EscribanoMolina2015.pdf (accessed on 28 September 2020).

61. Domínguez Castro, I.; Pineda Alfonso, J.A. Arte y creación en el aula de Infantil. Investig. Esc. 2019, 97, 64-83. [CrossRef]

62. Bowers, B. A look at early childhood programming in museums. J. Mus. Edu. 2012, 37, 39-47. [CrossRef]

63. Munley, M.E. Early Learning in Museums. A Review of Literature; Smithsonian: Washington, DC, USA, 2012. Available online: https:/ / www.si.edu/Content/SEEC/docs/mem\%20literature\%20review\%20early\%20learning $\% 20$ in $\% 20$ museums $\% 20$ final $\% 204 \% 2012 \% 202012$.pdf (accessed on 27 November 2020).

64. Monti, F.; Farné, R.; Crudeli, F.; Agostini, F.; Minelli, M.; Ceciliani, A. The role of outdoor education in child development in Italian nursery schools. Early Child Dev. Care 2019, 189, 867-882. [CrossRef]

65. Denzin, N.K.; Lincoln, Y.S. Strategies of Qualitative Inquiry, 4th ed.; Sage: Thousand Oaks, CA, USA, 2012.

66. Bisquerra, R. Metodología de la Investigación Educativa, 2nd ed.; La Muralla: Madrid, Spain, 2009.

67. Krippendorff, K. Content Analysis: An Introduction to Its Methodology; Sage: Los Angeles, CA, USA; Sage: London, UK, 2013.

68. European Commission. Commission Staff Working Documentt: Assesment of Key Competences in Initial Education and Training: Policy Guidance. Available online: https:/ / eur-lex.europa.eu/LexUriServ/LexUriServ.do?uri=SWD:2012:0371:FIN:EN:PDF (accessed on 21 October 2020).

69. Alonzo, A.C.; Steedle, J.T. Developing and assessing a force and motion learning progression. Sci. Edu. 2009, 93, 389-421. [CrossRef]

70. Jin, H.; Anderson, C.W. A learning progression for energy in socio-ecological systems. J. Res. Sci. Teach. 2012, 49, 1149-1180. [CrossRef]

71. Cuenca, J.M.; Estepa, J.; Martín, M.J. Heritage, education, identity and citizenship. Teachers and textbook in compulsory education. Rev. de Educ. 2017, 375, 131-152. [CrossRef]

72. García-Tormo, J.V. Aplicación de TICS (formularios on-line) como metodología docente activa en Estudios de Postgrado. Infad 2018, 3, 199-208. Available online: http:/ / www.infad.eu/RevistaINFAD/OJS/index.php/IJODAEP/article/view/1257/1096 (accessed on 29 October 2020). [CrossRef]

73. Pérez-Sanagustín, M.; Parra, D.; Verdugo, R.; García-Galleguillos, G.; Nussbaum, M. Using QR codes to increase user engagement in museum-like spaces. Comp. Hum. Behav. 2016, 60, 73-85. [CrossRef]

74. Dugard, P.; Todman, J. Analysis of pre-test post-test control group designs in educational research. Edu. Psych. 1995, 15, 181-198. [CrossRef]

75. Crespo, M.L.; Aguado, F.; Cuadrado, M.A. Tránsitos, un concepto distinto de exposición permanente. Boletín Asociación Amigos Museo Guadalajara 2007, 23, 117-145.

76. Aguado, F.; Cuadrado, M.A. Una nueva exposición permanente para el museo de Guadalajara, "El Palacio del infantado: Los Mendoza y el poder en Castilla". Circunstancias de su creación y desarrollo expositivo. Boletín Asociación Amigos Museo Guadalajara 2006, 6, 185-212.

77. Museo de Guadalajara. Available online: https://cultura.castillalamancha.es/museos/nuestros-museos/museo-de-guadalajara (accessed on 6 December 2020).

78. Abril-López, D.; García, C. Museo y ciencias sociales: Actividades didácticas para educación infantil. In X. Encuentro de Innovación en Docencia Universitaria: «al Futuro con el Pasado»; Castillo, H., García, P., Eds.; Universidad de Alcalá: Alcalá de Henares, Spain, 2019; pp. 105-114.

79. Hoskins, B.; Fredriksson, U. Learning to Learn: What is It Can It Be Measured? European Commission: Ispra, Italy, 2008. Available online: https: / / www.diva-portal.org/smash/get/diva2:128429/FULLTEXT01.pdf (accessed on 21 January 2021).

80. Maynard, T.; Waters, J. Learning in the outdoor environment: A missed opportunity? Early Years 2007, 27, 255-265. [CrossRef]

81. Abril-López, D.; Morón-Monge, M.C.; Morón-Monge, H.; Cuenca-López, J.M. The treatment of socioeconomic inequalities in the Spanish curriculum of the compulsory secondary education (ESO): An opportunity for interdisciplinary teaching. Soc. Sci. 2020, 9,94. [CrossRef] 